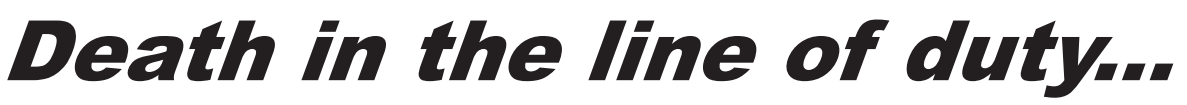

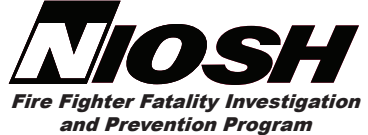

A summary of a NIOSH fire fighter fatality investigation

March, 2014

\section{Wildland Fire Fighter Suffers Sudden Cardiac Death During Campfire Patrol - New Mexico}

\section{Executive Summary}

On May 5, 2013, a 26-year-old male seasonal wildland fire fighter (FF), along with his two Engine crewmembers, conducted campfire patrol and terrain familiarization. After hiking with a wildland fire fighting pack for about 3 miles in hilly terrain over approximately 21/2-hours at 8000 feet, he reported feeling dizzy and suddenly collapsed. Initial assessment by crewmembers revealed labored breathing with a weak pulse. Shortly after crewmembers removed his pack, the FF became unresponsive with no pulse or respirations. One crewmember began cardiopulmonary resuscitation (CPR) as the other crewmember climbed a short distance to notify Dispatch by portable radio. Approximately 26 minutes later, the Lifeflight helicopter landed and initiated advanced life support (ALS). After 40 minutes of ALS, with no change in his clinical status, Medical Control advised the paramedics to cease resuscitation efforts and the FF was pronounced dead.

The autopsy report, completed by the State Medical Investigator, listed the cause of death as "dilated cardiomyopathy." NIOSH investigators conclude that the FF's sudden cardiac death was due to his previously undiagnosed dilated cardiomyopathy. His death may have been precipitated by the moderate physical exertion associated with hiking in hilly terrain at elevation.

NIOSH investigators offer the following recommendations to improve Agency safety and health among wildland fire fighters, however none of these recommendations would have prevented this FF's death. Implementing these recommendations will demonstrate a continuing commitment to improve the safety culture of the wildland fire service.

\section{Modify the Health Screening Questionnaire} (HSQ) to include all cardiovascular risk factors identified by the American Heart Association/ American College of Cardiology $(A H A / A C C)$.

Consider providing pre-placement and periodic medical evaluations to ALL fire fighters. The content of the evaluations should be consistent with NFPA 1582 or equivalent to determine their medical ability to perform duties without presenting a significant risk to the safety and health of themselves or others.

\section{Introduction \& Methods}

On May 5, 2013, a 26-year-old male wildland fire fighter suffered sudden cardiac death during campfire patrol and terrain familiarization. NIOSH was notified of this fatality on May 7 , 2013 by the United States Fire Administration and NIOSH contacted the employing Agency to gather additional information and initiate the investigation. On September 9, 2013, a Safety and Occupational Health Specialist from the NIOSH Fire Fighter Fatality Investigation Team investigated the incident. 


\section{Wildland Fire Fighter Suffers Sudden Cardiac Death During Campfire Patrol - New Mexico}

The National Institute for Occupational Safety and Health (NIOSH), an institute within the Centers for Disease Control and Prevention (CDC), is the federal agency responsible for conducting research and making recommendations for the prevention of work-related injury and illness. In 1998, Congress appropriated funds to NIOSH to conduct a fire fighter initiative that resulted in the NIOSH "Fire Fighter Fatality Investigation and Prevention Program" which examines line-of-duty-deaths or on duty deaths of fire fighters to assist fire departments, fire fighters, the fire service and others to prevent similar fire fighter deaths in the future. The agency does not enforce compliance with State or Federal occupational safety and health standards and does not determine fault or assign blame. Participation of fire departments and individuals in NIOSH investigations is voluntary. Under its program, NIOSH investigators interview persons with knowledge of the incident who agree to be interviewed and review available records to develop a description of the conditions and circumstances leading to the death(s). Interviewees are not asked to sign sworn statements and interviews are not recorded. The agency's reports do not name the victim, the fire department or those interviewed. The NIOSH report's summary of the conditions and circumstances surrounding the fatality is intended to provide context to the agency's recommendations and is not intended to be definitive for purposes of determining any claim or benefit. For further information, visit the program website at www.cdc.gov/niosh/fire or call toll free 1-800-CDC-INFO (1-800-232-4636). 


\section{Wildland Fire Fighter Suffers Sudden Cardiac Death During Campfire Patrol - New Mexico}

\section{Introduction \& Methods (cont.)}

During the investigation, NIOSH personnel interviewed the following people by phone or in person:

- Agency Regional Safety Manager

- Assistant District Fire Management Officer

- Agency Fire Fighter Medical Qualifications Program Manager

- Crewmembers

NIOSH personnel reviewed the following documents:

- FF's personnel folder

- Agency policies and operating guidelines

- Agency training records

- Agency "Fatality Facilitated Learning Analysis"

- Lifeflight helicopter medical incident report

- Autopsy report

- Agency medical records

\section{Investigative Results}

Incident. On May 5, 2013, the crew began their day at 0830 hours at their satellite wildland fire station. The Engine Captain briefed the crew on weather reports, a situational awareness report, and safety (stress and fatigue). At approximately 1011 hours, they refueled their Engine at the District office and headed out for campfire patrol and terrain familiarization.

At approximately 1300 hours, after lunch, the crew hiked into the hilly area to check for campfires and to train on various aspects of the terrain and potential fire behavior. Weather conditions included a temperature in the mid-sixties Fahrenheit $\left({ }^{\circ} \mathrm{F}\right)$ with a relative humidity of about $25 \%$. Crewmembers were wearing/carrying their typical wildland gear (green Nomex ${ }^{\circledR}$ pants, cotton tee-shirt, long sleeve Nomex shirt, boots, hardhat, gloves, and a 20-25 pound pack) and carried four canteens of water (about 1 gallon total). The hike covered 2-3 miles in hilly terrain over approximately 2 hours at an altitude of 8,000 feet.
At approximately 1500 hours, the crew turned around for the return hike to their Engine. At 1520 hours, they were about 1 mile from the Engine facing a steep incline. A crewmember asked the FF how he was feeling. The FF reported that he "was a little tired, but was fine." Hiking further up the incline, the crew stopped briefly to catch their breath. After hiking resumed, the FF began to wobble and reported feeling dizzy. The FF then fell to the ground but supported himself on his right elbow (1523 hours). The two crewmembers assessed him and found him to be unresponsive, with labored breathing and a weak pulse. Crewmembers removed his pack and within 30 seconds he stopped breathing and was pulseless. One crewmember began CPR while the other crewmember hiked about 30 feet up the incline to radio Dispatch (1526 hours).

After alerting Dispatch, the crewmember hiked back to the FF's location and assisted with CPR as a Lifeflight helicopter and a ground ambulance were dispatched (1532 hours). CPR continued for $32 \mathrm{~min}$ utes with no change in the FF's clinical status. The helicopter landed at 1558 hours and the flight medics found the FF unresponsive, not breathing, and pulseless with CPR in progress. A cardiac monitor showed ventricular fibrillation; three shocks were administered. The FF was intubated, oxygen was administered via bag-valve-mask, an intravenous line was placed, and cardiac resuscitation medications were administered with no positive change in the FF's clinical status. At 1638 hours, after conferring with Medical Control, resuscitation efforts were stopped and the FF was pronounced dead.

Medical Findings. The autopsy report, completed by the State Medical Investigator, listed the cause of death as "dilated cardiomyopathy." Pertinent findings from the autopsy (Appendix A) included the following: an enlarged heart (470 grams), evidence of left 


\section{Wildland Fire Fighter Suffers Sudden Cardiac Death During Campfire Patrol - New Mexico}

\section{Investigative Results (cont.)}

ventricular hypertrophy, normal heart valves, no conduction system abnormalities, and no coronary artery disease or thrombus. Other pertinent findings included positive blood tests for medications (antidepressant, muscle relaxant, and sedative), nicotine, and caffeine.

The FF had no previous cardiac problems, however, according to the medical examiner's report, the FF suffered a syncopal episode witnessed by his sister about 6-8 months prior to his death. At the time of this report, the FF's personal medical records were not available to the NIOSH investigator. He was 78" tall and weighed 199 pounds, giving him a body mass index (BMI) of 23. A BMI of 18.5-24.9 is considered "normal" [CDC 2011]. He was physically fit and active on a daily basis. The FF passed his most recent pack test (see description in the following section) in April 2013.

\section{Agency's Wildland Fire Fighter Program}

Employment and Training. The Agency requires all new wildland fire fighter I or II applicants to complete an application and possess wildland firefighting certification otherwise known as the "Red Card." The red card is acquired by the following:

1) completing five initial courses: Introduction to ICS (I-100), Firefighter Training (S-130), Introduction to Wildland Fire Behavior (S-190), Human Factors on the Fireline (L-180), NIMS: An Introduction (IS700), and Annual Fireline Safety Refresher (RT-130)

2) completing a health screening questionnaire (HSQ) (Appendix B), and

3) passing a work capacity test (for the fire fighter position this requires the "arduous pack test"). The pack test requires the applicant to hike 3 miles in 45 minutes or less while wearing a 45-pound pack.
The full-time applicant is then referred for a drug test and a background check before receiving a job offer from the Agency. If any applicant responded with a "yes" on their HSQ, the applicant is referred for a preplacement medical evaluation. The FF did not receive a medical evaluation, but received his red card on April 8, 2013 and certified as a fire fighter type II (FFT2).

The Agency has listed the essential job functions and work conditions for Forestry Aides (wildland fire fighters) (Appendix C). Once certified, wildland fire fighters can work on a variety of fire units. Engine crews consist of three crewmembers who operate out of a wildland fire station. The FF had worked on an engine crew for 1 month prior to his death.

\section{Preplacement and Periodic Medical Evaluations.}

The Agency does not require a preplacement (baseline) or a periodic medical evaluation for any fire fighter positions. However, the applicant must complete the HSQ. If the applicant answers "yes" to any question, a medical evaluation by a physician is required. The FF completed his HSQ on April 2, 2013 and answered "no" to all the health questions. The HSQ does not query about prescription medications, smoking status, or weight. The Agency plans to implement a medical evaluation program that will require all personnel with an arduous duty qualification to obtain a preplacement medical evaluation and a periodic medical evaluation every 3 years. The Agency will not distinguish between temporary or permanent positions or by age.

Fitness Programs. The Agency supports fitness activities for all its employees by encouraging participation in daily exercise. The FF regularly exercised by hiking and by performing pushups and situps. 


\section{Wildland Fire Fighter Suffers Sudden Cardiac Death During Campfire Patrol - New Mexico}

\section{Discussion}

Cardiomyopathy. Although the FF was asymptomatic, the autopsy revealed dilated cardiomyopathy. Cardiomyopathies involve damage to the heart muscle not due to hypertension, ischemia (coronary artery disease), valvular, pericardial, or congenital heart disease [Wynne and Braunwald 2008]. The three types of cardiomyopathy based on functional impairment are:

1) dilated, the most common form, accounts for $60 \%$ of all cardiomyopathies

2) hypertrophic, recognized by left ventricular hypertrophy, often with involvement of the interventricular septum and right ventricle

3 ) restrictive, the least common form in Western countries, marked by impaired diastolic filling and in some cases with endocardial scarring of the ventricle [Wynne and Braunwald 2008]

Dilated cardiomyopathy is characterized by cardiac enlargement and impaired systolic function of one or both ventricles, congestive heart failure, arrhythmias, and emboli [Dec and Fuster 1994]. As the ventricular function deteriorates, the following signs and symptoms of congestive heart failure appear: shortness of breath with exertion or when lying flat, ankle swelling, fatigue, and/ or weakness. Laboratory studies such as cardiac catheterization, echocardiogram, or imaging studies are necessary to make the diagnosis of dilated cardiomyopathy. Microscopic findings are nonspecific, typically being myocyte hypertrophy (best appreciated as nuclear hypertrophy ["boxcar nuclei"]) with varying degrees of interstitial fibrosis [Dec and Fuster 1994; Virmani 1997; Wynne and Braunwald 2008].

The incidence rate of dilated cardiomyopathy in the United States is 5 to 8 cases per 100,000 per year, with an age-adjusted prevalence of 36 cases per 100,000 [Virmani 1997]. Although most cases of dilated cardiomyopathy are of unknown etiology (idiopathic), a variety of acquired or hereditary disorders can cause the disorder. These secondary and potentially reversible forms are listed in Appendix D [Dec and Fuster 1994]. It is unlikely the FF had any of these secondary causes.

Inherited factors account for approximately one third of all idiopathic dilated cardiomyopathy cases [Fatkin et al. 1999]. Although the FF did not have a family history of idiopathic dilated cardiomyopathy, this is the most likely etiology. The FF's first-degree relatives (parents, siblings, and children) should consult with their physicians regarding if or when a screening echocardiogram is warranted.

Dilated cardiomyopathy is associated with an increased incidence of sudden cardiac death [Dec and Fuster 1994; Bansch et al. 2002; Wynne and Braunwald 2008]. Although sudden death is rarely the initial presentation [Komajda et al. 1990; Sugrue et al. 1992], it is a common cause of death among idiopathic dilated cardiomyopathy patients, accounting for $28 \%$ of all idiopathic dilated cardiomyopathy deaths [Dec and Fuster 1994]. Although a variety of symptoms and medical tests can provide prognostic information, patients at greatest risk of sudden cardiac death are hard to identify [Dec and Fuster 1994]. In this case the FF's initial presentation of his dilated cardiomyopathy was sudden cardiac death.

Epidemiologic studies have found that heavy physical exertion sometimes precedes and triggers sudden cardiac death [Albert et al. 2000]. Among structural fire fighters, sudden cardiac events have 


\section{Wildland Fire Fighter Suffers Sudden Cardiac Death During Campfire Patrol - New Mexico}

\section{Discussion (cont.)}

been associated with alarm response, fire suppression, and heavy exertion during training (including physical fitness training) [Kales et al. 2003; Kales et al. 2007; NIOSH 2007]. The FF was hiking at 8,000 feet in hilly terrain for about 3 miles over a period of $2^{1 / 2}$ hours while wearing/carrying a traditional wildland fire fighter gear pack weighing approximately 25 pounds). This activity would have expended about 8 METs, which is considered moderate physical activity [AIHA 1971;

Sharkey and Gaskill 2009; Ainsworth et al. 2011]. NIOSH investigators conclude that the FF had a fatal cardiac arrhythmia due to his dilated cardiomyopathy. His death possibly was triggered by his moderate physical activity during the terrain familiarization hike.

Primary Arrhythmia. A primary cardiac arrhythmia (e.g., ventricular tachycardia/fibrillation) was probably responsible for the FF's sudden cardiac death. Lethal ventricular arrhythmias account for most sudden cardiac deaths [Kelesidis and Travin 2012]. Risk factors for arrhythmias include cardiac disease, heart attack, sleep apnea, dietary supplements, smoking, alcohol, drug abuse, medications, diabetes, and hyperthyroidism [AHA 2012; Mayo Clinic 2013]. The FF's autopsy revealed dilated cardiomyopathy and two other cardiac findings associated with dilated cardiomyopathy: cardiomegaly and left ventricular hypertrophy. All three of these cardiac findings increase the risk for primary arrhythmia [Levy et al. 1990; AHA 2012; Tavora et al. 2012].

\section{Occupational Medical Standards for Structural} Fire Fighters. To reduce the risk of sudden cardiac arrest or other incapacitating medical conditions among fire fighters, the NFPA developed NFPA 1582, Standard on Comprehensive Occu- pational Medical Program for Fire Departments [NFPA 2013]. This voluntary industry standard provides the components of a preplacement and annual medical evaluation and medical fitness for duty criteria. The FF was young and asymptomatic. There was no indication or suspicion of any underlying cardiac conditions, therefore he was given medical clearance for unrestricted duty based on his answers on his HSQ and having passed his "pack test."

The FF was prescribed a sedative, an antidepressant, and a muscle relaxant. It is unclear when these were prescribed. NFPA 1582 lists sedatives as Category A medications and antidepressant and muscle relaxants as Category B medications. A candidate with Category A medication or condition shall not be certified as meeting the medical requirements of the standard [NFPA 2013]. A candidate with Category B medication or condition shall be certified as meeting the medical requirements of the standard only if they can perform the essential job tasks without posing a significant safety and health risk to themselves, members, or civilians [NFPA 2013]. The HSQ does not provide any questions or space to report current prescription medications.

\section{Recommendations}

\section{Recommendation \#1: Modify the Health Screening Questionnaire (HSQ) to include all cardiovascular risk factors identified by the American Heart Associ- ation/American College of Cardiology (AHA/ACC).}

The HSQ does not cover all coronary artery disease risk factors identified by the AHA/ACC. Specifically, the HSQ includes no question regarding prescription medications, smoking status, and weight. We suggest 


\section{Wildland Fire Fighter Suffers Sudden Cardiac Death During Campfire Patrol - New Mexico}

\section{Recommendations (cont.)}

replacing these yes/no questions with questions that require the fire fighter to enter specific information (see Appendix E). The WCT Administrator would then decide whether the fire fighter was fit to perform the WCT. Using these "fill in the blank" type of questions puts more responsibility on fire fighters to know the results of their medical tests.

\section{Recommendation \#2: Consider providing pre-} placement and periodic medical evaluations to ALL fire fighters. The content of the evaluations should be consistent with NFPA 1582 or equivalent to determine medical ability to perform duties without presenting a significant risk to the safety and health of themselves or others.

Guidance regarding medical evaluations can be found in NFPA 1051, Standard for Wildland Fire Fighter Professional Qualifications [NFPA 2012], which refers the reader to NFPA 1582, Standard on Comprehensive Occupational Medical Program for Fire Departments [NFPA 2013]. NFPA 1051 states the guidance in NFPA 1582 might need to be modified for individuals involved in the suppression of wildland fires. Additional guidance can be found in the report of the International Association of Fire Fighters/International Association of Fire Chiefs (IAFF/IAFC) wellness/fitness initiative [IAFF/IAFC 2008].

The Agency is not legally required to follow any of these standards. The success of medical programs hinges on protecting the affected fire fighter. The Agency must 1) keep the medical records confidential, and 2) if the fire fighter is not medically qualified for active fire fighting duties, notify the fire fighter of the medical findings. The Agency is currently providing both preplacement medical evaluations only to personnel who answer "yes" on their HSQ. No periodic medical evaluations are offered.

\section{References}

AHA [2012]. Understand your risk for arrhythmia. Dallas, TX: American Heart Association. [http:// www.heart.org/HEARTORG/Conditions/Arrhyth$\mathrm{mia} /$ UnderstandYourRiskforArrhythmia/Understand-Your-Risk-for-Arrhythmia_UCM_002024 Article.jsp]. Date accessed: December 2013.

AHA [2013]. Chain of survival. Dallas, TX: American Heart Association. [http://www.heart. org/HEARTORG/CPRAndECC/WhatisCPR/ EC $\neg$ CIntro/Chain-of-Survival_UCM_307516_Article.jsp]. Date accessed: December 2013.

AIHA [1971]. Ergonomics guide to assessment of metabolic and cardiac costs of physical work. Am Ind Hyg Assoc J 32(8):560-564.

Ainsworth BE, Haskell WL, Herrmann SD, Meckes N, Bassett DR Jr, Tudor-Locke C, Greer JL, Vezina J, Whitt-Glover MC, Leon AS [2011]. Compendium of physical activities: a second update of codes and MET values. Med Sci Sports Exerc 43(8):1575-1581.

Albert CM, Mittleman MA, Chae CU, Lee IM, Hennekens CH, Manson JE [2000]. Triggering of sudden death from cardiac causes by vigorous exertion. N Engl J Med 343(19):1355-1361.

Bansch D, Antz M, Boczor S, Volkmer M, Tebbenjohanns J, Seidl K, Block M, Gietzen F, Berger J, Kuck KH [2002]. Primary prevention of sudden cardiac death in idiopathic dilated cardiomyopathy. The cardiomyopathy trial (CAT). Circulation 105(12):1453-1458. 


\section{Wildland Fire Fighter Suffers Sudden Cardiac Death During Campfire Patrol - New Mexico}

\section{References (cont.)}

CDC (Centers for Disease Control and Prevention) [2013]. BMI - Body Mass Index. [www.cdc. gov/nccdphp/dnpa/bmi/adult_BMI/english_bmi calculator/bmi_calculator.htm]. Date accessed: December 2013.

Dec GW and Fuster V [1994]. Medical progress: idiopathic dilated cardiomyopathy. N Engl J Med 331(23):1564-1575.

Fatkin D, MacRae C, Sasaki T, Wolff MR, Porcu M, Frenneaux M, Atherton J, Vidaillet HJ, Spudich S, De Girolami U, Seidman JG, Seidman CE, Muntoni F, Muehle G, Johnson W, McDonough B [1999]. Missense mutations in the rod domain of the Lamin $\mathrm{A} / \mathrm{C}$ gene as causes of dilated cardiomyopathy and conduction-system disease. N Engl J Med 341(23):1715-1724.

IAFF, IAFC [2008]. The fire service joint labor management wellness/fitness initiative. 3rd ed. Washington, DC: International Association of Fire Fighters, International Association of Fire Chiefs.

Kales SN, Soteriades ES, Christoudias SG, Christiani DC [2003]. Firefighters and on-duty deaths from coronary heart disease: a case control study. Environ health: a global access science source. 2:14. [http://www.ehjournal.net/content/2/1/14]. Date accessed: December 2013.

Kales SN, Soteriades ES, Christophi CA, Christiani DC [2007]. Emergency duties and deaths from heart disease among fire fighters in the United States. N Engl J Med 356(12):1207-1215.
Komajda M, Jais JP, Reeves F, Goldfarb B, Bouhour JB, Juillieres Y, Lanfranchi J, Peycelon P, Geslin PH, Carrie D, Grosgogeat Y [1990]. Factors predicting mortality in idiopathic dilated cardiomyopathy. Eur Heart J 11(9):824-831.

Kelesidis I and Travin MI [2012]. Use of cardiac radionuclide imaging to identify patients at risk for arrhythmic sudden cardiac death. J Nucl Cardiol 19(1):142-152.

Koster RW [2002]. Automatic external defibrilla $\neg$ tor: key link in the chain of survival. $\mathrm{J}$ Cardiovasc Electrophysiol 13(1 Suppl):S92-95.

Levy D, Garrison RJ, Savage DD, Kannel WB, Castelli WP [1990]. Prognostic implications of echocardiographically determined left ventricular mass in the Framingham Heart Study. N Engl J Med 323(24):1706-1707.

Link MS, Atkins DL, Passman RS, Halperin HR, Samson RA, White RD, Cudnik MT, Berg MD, Kudenchuk PJ, Kerber RE [2010]. Part 6: Electri $\neg$ cal therapies: automated external defibrillators, defibrillation, cardioversion, and pacing. 2010 American Heart Association Guidelines for car $\neg$ diopulmonary resuscitation and emergency cardio $\neg$ vascular care. Dallas, TX: American Heart Associᄀation. [http://circ.ahajournals.org/content/122/18_suppl_3/S706.full.pdf+html]. Date accessed: December 2013.

Marenco JP, Wang PJ, Link MS, Homoud MK, Estes NA 3rd [2001]. Improving survival from sudden cardiac arrest: the role of the automated external defibrillator. JAMA 285(9):1193-1200. 


\section{Wildland Fire Fighter Suffers Sudden Cardiac Death During \\ Campfire Patrol - New Mexico}

\section{References (cont.)}

Mayo Clinic [2013]. Heart arrhythmias. [http:// www.mayoclinic.com/health/heart-arrhythmias/ DS00290/METHOD=print\&DSECTION=all]. Date accessed: December 2013.

NFPA [2012]. Standard for wildland fire fighter professional qualifications. Quincy, MA: National Fire Protection Association. NFPA 1051.

NFPA [2013]. Standard on comprehensive occupational medical program for fire departments. Quincy, MA: National Fire Protection Association. NFPA 1582.

NIOSH [2007]. NIOSH alert: preventing fire fighter fatalities due to heart attacks and other sudden cardiovascular events. [http://www.cdc. gov/niosh/docs/2007-133/]. Cincinnati, OH: U.S. Department of Health and Human Services, Centers for Disease Control and Prevention, National Institute for Occupational Safety and Health, DHHS (NIOSH) Publication No. 2007-133.

Sasson C, Rogers MAM, Dahl J, Kellermann AL [2010]. Predictors of survival from out-ofhospital cardiac arrest, a systematic review and meta-anal $\neg$ ysis. Circ Cardiovasc Qual Outcomes 3(1):63-81.

Sharkey BJ, Gaskill SE [2009]. Fitness and work capacity. 2009 Edition. National Wildland Coordinating Group. PMS 304-2, NFES 1596. [http:// www.nwcg.gov/pms/pubs/pms304-2.pdf]. Date accessed: December 2013.

Siegel RJ [1997]. Myocardial hypertrophy. In: Bloom S, ed. Diagnostic criteria for cardiovascular pathology acquired diseases. Philadelphia, PA: Lippencott-Raven, pp. 55-57.
Sugrue DD, Rodeheffer RJ, Codd MB, Ballard DJ, Fuster V, Gersh BJ [1992]. The clinical course of idiopathic dilated cardiomyopathy: a populationbased study. Ann Intern Med 117(2):117-123.

Tavora F, Zhang Y, Zhang M, Li L, Ripple M, Fowler D, Burke A [2012]. Cardiomegaly is a common arrhythmogenic substrate in adult sudden cardiac deaths, and is associated with obesity. Pathol 44(3):187-191.

Virmani R [1997]. Cardiomyopathy, idiopathic dilated. In: Bloom S, ed. Diagnostic criteria for cardiovascular pathology acquired diseases. Philadelphia, PA: Lippencott-Raven, pp. 26-27.

Weisfeldt ML, Everson-Stewart S, Sitlani C, Rea T, Aufderheide TP, Atkins DL, Bigham B, Brooks SC, Foerster C, Gray R, Ornato JP, Powell J, Kudenchuk PJ, Morrison LJ [2011]. Ventricular tachyarrhythmias after cardiac arrest in public versus at home. N Engl J Med 364(4):313-321.

Wynne J, Braunwald E [2008]. Cardiomyopathy and myocarditis. In: Fauci AS, Braunwald E, Kasper DL, Hauser SL, Longo DL, Jameson JL, Loscalzo J, eds. Harrison's principles of internal medicine. 17th ed. New York: McGraw-Hill, pp. 1481-1488. 


\section{Wildland Fire Fighter Suffers Sudden Cardiac Death During \\ Campfire Patrol - New Mexico}

\section{Investigator Information}

This incident was co-investigated by the two members of the NIOSH Fire Fighter Fatality Investigation and Prevention Program, Cardiovascular Disease Component located in Cincinnati, Ohio. Tommy Baldwin, MS, is a safety and occupational health specialist, a National Association of Fire Investigators (NAFI) certified fire and explosion investigator, an International Fire Service Accreditation Congress (IFSAC) Certified Fire Officer I, and a former fire chief and emergency medical technician. Thomas Hales, MD, MPH, is board certified in Occupational and Environmental Medicine, and Internal Medicine as is a member of the NFPA Technical Committee on Occupational Safety and Heath, and vice chair of the Public Safety Medicine Section of the American College of Occupational and Environmental Medicine (ACOEM). NIOSH investigators acknowledge the cooperation and assistance of Agency managers and crewmembers during the investigation. 


\section{Wildland Fire Fighter Suffers Sudden Cardiac Death During \\ Campfire Patrol - New Mexico}

\section{Appendix A}

- Dilated cardiomyopathy

\section{Autopsy Findings}

- Ventricles and atrioventricular valves dilated bilaterally; the right ventricle more than the left (no measurement documented)

- Tricuspid valve measured 15.4 centimeters $(\mathrm{cm})$

- Normal is $11.63 \mathrm{~cm}$ [Westaby et al. 1984]

- Mitral valve measured $12.9 \mathrm{~cm}$

- Normal is $9.79 \mathrm{~cm}$ [Westaby et al. 1984]

- Cardiomegaly (enlarged heart; heart weighed 470 grams [g]; predicted normal weight is $371 \mathrm{~g}$ [ranges between $281 \mathrm{~g}$ and $489 \mathrm{~g}$ as a function of sex, age, and body weight]) [Silver and Silver 2001]

- Left ventricular hypertrophy

$\circ$ Left ventricle and interventricular septum thickened (1.3 centimeter [ $\mathrm{cm}]$ and $1.1 \mathrm{~cm}$ respectively)

- Normal at autopsy is $0.76-0.88 \mathrm{~cm}$ [Colucci and Braunwald 1997]

- Normal by echocardiographic measurement is $0.6-1.0 \mathrm{~cm}$ [Connolly and $\mathrm{Oh} 2012$ ]

- Normal cardiac valves

- No evidence of a coronary artery thrombus (blood clot)

- No evidence of coronary artery atherosclerosis

- No evidence of a pulmonary embolus (blood clot in the lung arteries)

- Blood tests for drugs and alcohol revealed therapeutic levels of:

- Sertraline (34 nanograms per millileter [ng/mL]), an antidepressant

○ Desmethylsertraline $(55 \mathrm{ng} / \mathrm{mL})$, Sertraline's metabolite

- Cyclobenzaprine $(8.6 \mathrm{ng} / \mathrm{mL})$, a muscle relaxant

○ Nordiazepam $(34 \mathrm{ng} / \mathrm{mL})$, a sedative

- Microscopic evidence of myocyte hypertrophy, focal areas of interstitial fibrosis, and scattered areas of contraction band necrosis

\section{References}

Colucci WS, Braunwald E [1997]. Pathophysiology of heart failure. In: Braunwald, ed. Heart disease. 5th ed. Philadelphia, PA: W.B. Saunders Company, p. 401.

Connolly HM, Oh JK [2012]. Echocardiography. In: Bonow RO, Mann DL, Zipes DP, Libby P, Braunwald E, eds. Heart disease: a text of cardiovascular medicine. 9th ed. Vol. 1. Philadelphia, PA: Elsevier Saunders, p. 216.

Silver MM, Silver MD [2001]. Examination of the heart and of cardiovascular specimens in surgical pathology. In: Silver MD, Gotlieb AI, Schoen FJ, eds. Cardiovascular pathology. 3rd ed. Philadelphia, PA: Churchill Livingstone, pp. 8-9.

Westaby S, Karp RB, Blackstone EH, Bishop SP [1984]. Adult human valve dimensions and their surgical significance. Am J Cardiol 53(4):552-556. 


\title{
Wildland Fire Fighter Suffers Sudden Cardiac Death During Campfire Patrol - New Mexico
}

\section{Appendix B}

\author{
WCT LEVEL \\ Arduous \\ Moderate \\ Light \\ USDA Forest Service/Department of the Interior FS-5100-31 (Rev 8/2009) OMB 0596-0164 (Expires1/2013)
}

\section{HEALTH SCREENING QUESTIONNAIRE (HSQ)}

Assess your health needs by marking all true statements.

The purpose is to identify individuals who may be at risk in taking the Work Capacity Test (WCT) and recommend an exercise program and or medical examination prior to taking the WCT.

Employees are required to the following questions. The questions were designed, in consultation with occupational health physicians, to identify individuals who may be at risk when taking a WCT. The HSQ is not a medical examination. Any medical concerns you have that place you or your health at risk should be reviewed with your personal physician prior to participating in the WCT.

Check 'Yes' or 'No' in response to the following questions:
[ ] Y [ ] N 1) During the past 12 months have you at any time (during physical activity or while resting) experienced pain, discomfort or pressure in your chest?
[ ] Y [ ] N $\quad$ 2) During the past 12 months have you experienced difficulty breathing or shortness of breath, dizziness, fainting, or blackout?
[ ] Y [ ] N 3) Do you have a blood pressure with systolic (top \#) greater than 140 or diastolic (bottom \#) greater than 90 ?
[ ] Y [ ] N 4 4) Have you ever been diagnosed or treated for any heart disease, murmur, chest pain (angina), palpitations (irregular beat), or heart attack?
[ ] ] [ ] N 5) Have you ever had heart surgery, angioplasty, a pacemaker, valve replacement, or heart transplant?
[ ] Y [ ] N $\quad$ 6) Do you have a resting pulse greater than 100 beats per minute?
[ ] $\mathrm{Y}$ [ ] N $\quad$ 7) Do you have any arthritis, back trouble, hip/knee/joint pain, or any other bone or joint condition that could be aggravated or made worse by the Work Capacity Test?
[ ] Y [ ] N $\quad$ 8) Do you have personal experience or a doctor's advice of any other medical or physical reason that would prohibit you from taking the Work Capacity Test?
[ ] Y [ ] N 19 9) Has your personal physician recommended against taking the Work Capacity Test because of asthma, diabetes, epilepsy or elevated cholesterol or hernia?

Regardless of whether you are taking the Work Capacity Test at the Arduous, Moderate or Light duty level, a "Yes" answer requires a determination from your personal physician stating that you are able to participate.

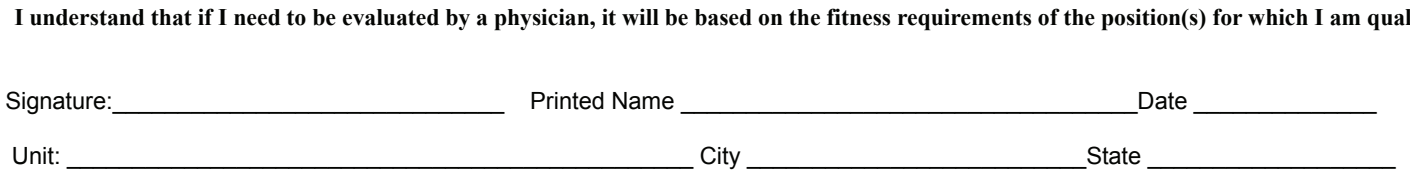




\title{
Wildland Fire Fighter Suffers Sudden Cardiac Death During Campfire Patrol - New Mexico
}

\section{Appendix B (cont.)}

Risks

\author{
Work Capacity Test: Informed Consent
}

$i \quad$ There is a slight risk of injury (blisters, sore legs, sprained ankles) especially for those who have not practiced the test. If you have been inactive and have not practiced or trained for the test, you should engage in several weeks of specific training before you take the test. Be certain to warm up and stretch before taking the test, and to cool down after the test. The risk of more serious consequences (such as respiratory or heart problems) is diminished by completing the (HSQ) physical activity readiness questionnaire.

¿ Pack Test- Arduous The 3-mile test with a 45

pound pack in 45 minutes is strenuous, but no more so than the duties of wildland firefighting.

¿ Field Test-Moderate The 2-mile test with a 25 pound pack in 30 minutes is fairly strenuous, but no more so than the field duties.

$¿ \quad$ Walk Test-Light The 1-mile walk in 16 minutes is moderately strenuous, but no more so than the duties assigned.

[ ] I have read the information on this form, the brochure "Work Capacity Test" and understand the purpose, instructions, and risks of the job related to work capacity test.

[ ] I have read the information, understood, and truthfully answered the HSQ.

Test to be Taken (check one) Pack test [ ] Field Test [ ] Walk Test [ ]

Signature Date

Date

Printed Name

Baseline Vitals: Time Heart Rate Blood pressure

Emergency Contact Information:

Name Phone

Relationship

Privacy Statement

The information obtained in the completion of this form is used to help determine whether an individual being considered for wildland firefighting can carry out those duties in a manner that will not place the candidate unduly at risk due to inadequate physical fitness and health. Its collection and use are covered under Privacy Act System of Records OPM/Govt-10 and are consistent with the provisions of 5 USC 552a (Privacy Act of 1974).

According to the Paperwork Reduction Act of 1995, an agency may not conduct or sponsor, and a person is not required to respond to a collection of information unless it displays a valid OMB control number. The valid OMB control number for this information collection is $0596-0164$. The time required to complete this information collection is estimated to average 5 minutes per response, including the time for reviewing instructions, searching existing data sources, gathering and maintaining the data needed, and completing and reviewing the collection of information. The U.S. Department of Agriculture (USDA) prohibits discrimination in all its programs and activities on the basis of race, color, national origin, gender, religion, age, disability, political beliefs, sexual orientation, and marital or family status. (Not all prohibited bases apply to all programs.) Persons with disabilities who require alternative means for communication of program information (Braille, large print, audiotape, etc.) should contact USDA's TARGET Center at 202-720-2600 (voice and TDD). To file a complaint of discrimination, write USDA, Director, Office of Civil Rights, 1400 Independence Avenue, SW, Washington, DC 20250-9410 or call (800) 975-3272 (voice) or (202) 720-6382 (TDD). USDA is an equal opportunity provider and employer. 


\section{Wildland Fire Fighter Suffers Sudden Cardiac Death During Campfire Patrol - New Mexico}

\section{Appendix C}

\section{Forestry Aide Job Description}

The position may be filled as a temporary appointment up to 6 months or as a not to exceed 1 year which can be extended 1 additional year.

Serves on crews performing duties in fire prevention and suppression. Performs prescribed burning crew duties in order to reduce fuel hazards and disease, while protecting wildlife. Assists with fire dispatch through operation of radios, telephones, and other necessary equipment to exchange information for fire weather and other forest suppression activities.

Lays or directs hose in the use of water. Moves dirt, chops brush, and fells small trees to build fireline using various hand tools such as axes, shovels, Pulaskis, and McLeods to control spreading wildland fire and/or to prepare lines prior to controlled burning. Chops, carries, and piles logging slash. Searches out and extinguishes burning materials by moving dirt, applying water by hose or backpack pump. Patrols fireline to locate and extinguish sparks, flare-ups, and hot sports that may threaten loss of control of the fire. Cleans, reconditions, and stores simple fire tools and equipment.

Performs basic duties in support of fire, timber, silviculture, recreation, wilderness, or research programs, projects, or activities. 


\section{Wildland Fire Fighter Suffers Sudden Cardiac Death During \\ Campfire Patrol - New Mexico}

\section{Appendix D}

\section{Known Causes of Dilated Cardiomyopathy [Dec and Fuster 1994]}

$\underline{\text { Toxins }}$

Ethanol

Chemotherapeutic agents (doxorubicin, bleomycin)

Cobalt

Anti-retroviral agents (zidovudine, didanosine, zalcitabine)

Phenothiazines

Carbon monoxide

Lead

Cocaine

Mercury

Metabolic Abnormalities

Nutritional deficiencies (thiamine, selenium, carnitine)

Endocrinologic disorders (hypothyroidism, acromegaly, thyrotoxicosis,

Cushing disease, pheochromocytoma, diabetes mellitus)

Electrolyte disturbances (hypocalcemia, hypophosphatemia)

$\underline{\text { Infectious }}$

Viral (coxsackie virus, cytomegalovirus, human immunodeficiency virus)

Rickettsial

Bacterial (diphtheria)

Mycobacterial

Fungal

Parasitic (toxoplasmosis, trichinosis, Chagas disease)

\section{Noninfectious}

Collagen vascular disorders (scleroderma, lupus erythematosus, dermatomyositis)

Hypersensitivity myocarditis

Sarcoidosis

Peripartum dysfunction

\section{Neuromuscular Causes}

Duchenne muscular dystrophy

Facioscapulohumeral muscular dystrophy

Erb limb-girdle dystrophy

Myotonic dystrophy 


\section{Wildland Fire Fighter Suffers Sudden Cardiac Death During Campfire Patrol - New Mexico}

\section{Appendix E}

History:

- Male older than 45 years

- Female older than 55 years

- Father or brother has had a heart attack before age 55

- Mother or sister has had a heart attack before age 65

- Smoker

- Previously diagnosed with hypertension (high blood pressure)

o Take prescription medication for high blood pressure

o Most recent blood pressure measurement

o Date of most recent blood pressure measurement

- Previously diagnosed with hypercholesterolemia/hyperlipidemia (high blood cholesterol)

o Take prescription medication for high blood cholesterol

o Most recent cholesterol levels (e.g., low density lipoprotein [LDL], total cholesterol/high density lipoprotein [HDL] ratio)

o Date of most recent cholesterol measurement

- Previously diagnosed with diabetes mellitus

o Take prescription medication for diabetes

o Most recent blood sugar measurement

o Date of most recent blood sugar measurement

Current height:

Current weight:

Current prescription medications:

Physically inactive (i.e., you get less than 30 minutes of exercise at least 3 days per week) 